\title{
UPAYA MEMPERBAIKI MISKONSEPSI DAN HASIL BELAJAR SISWA KELAS XI-IPA 1 SMAN 2 BAU-BAU MELALUI PENERAPAN MODEL PEMBELAJARAN ICI (INTERACTIVE CONCEPTUAL INSTRUCTION) BERBANTUAN LKS BERBASIS LINGKUNGAN
}

\author{
Ummi Salamah \\ SMAN 2 Bau-Bau, Kota Kendari Sulawesi Tenggara \\ e-mail: ummibaubau@gmail.com
}

\begin{abstract}
Abstrak
Pemahaman terhadap alam dan lingkungan merupakan salah satu modal dasar untuk menyongsong kehidupan di masa mendatang, yang semuanya bergantung pada temuan-temuan dan terobosan-terobosan dalam bidang sains dan teknologi. Penelitian ini bertujuan untuk memperbaiki miskonsepsi dan hasil belajar fisika siswa kelas XI-IPA melalui penerapan model pembelajaran ICI berbantuan LKS berbasis lingkungan. Jenis penelitianini adalah classroom action research. Pelaksaan penelitian terdiri dari dua siklus yaitu siklus 1 dan siklus 2 dengan tahapan pada masing-masing siklus yaitu perencanaan, tindakan, observasi, evaluasi dan refleksi. Subjek penelitian adalah siswa kelas $\mathrm{XI}_{-I P A_{1}}$ SMAN 2 Bau-Bau dengan jumlah siswa 35 orang.Intrument penelitian dan teknik pengumpulan data terdiri dari tes miskonsepsi, tes hasil belajar, lembar observasi psikomotorik, dan lembar observasi afektif. Sedangkan teknikan alisis data menggunakan analisis deksriptif kuantitatif dan kualitatif yang terdiri dari analisis ketuntasan secara klasikal. Hasil analisis menunjukkan bahwa terjadi peningkatan hasil belajar dari siklus 1 dan siklus 2 dari segikognitif, afektif dan psikomotorik. Sedangkan pada tinjauan miskonsepsi terjadi perubahan dari siklus 1 ke siklus 2 . Sehingga dapat dikatakan bahwa model ICI dapat mereduksi miskonsepsi siswa dan dapat meningkatkan hasil belajar siswa.
\end{abstract}

Kata kunci: Model ICI, Miskonsepsi, Hasil Belajar, Pembelajaran Fisika, LKS

\section{Abstract}

An understanding of nature and the environment is one of the initial capital to meet future life, which all depend on the findings and breakthroughs in science and technology. This study aims to improve the misconceptions and physics learning outcomes of class XI-IPA students through the application of an environment-based worksheet based ICI learning. This type of research is Classroom Action Research. Implementation study consisted of two cycles of cycle one and cycle 2 with stages in each cycle of planning, action, observation, evaluation, and reflection. The research subjects were students of class XI-IPA Senior High School of 2 Bau-Bau with a total of 35 students. Research instruments and data collection techniques consisted of misconception tests, learning outcomes tests, psychomotor observation sheets, and affective observation sheets-data analysis technique using descriptive analysis of quantitative and qualitative consisting of completeness in classical analysis. The study showed that an increase in the learning outcomes of cycle one and cycle 2 in terms of cognitive, affective, and psychomotor. While on a review of misconceptions changes from cycle 1 to cycle 2. So it can be said that the $\mathrm{ICl}$ model can reduce student misconceptions and can improve student learning outcomes.

Keywords : ICI Model, Misconception, Learning Outcomes, Learning Physics, Student Worksheet 


\section{Pendahuluan}

Pelajaran fisika adalah salah satu mata pelajaran yang termasuk kedalam IPA. Hal yang dipelajari dalam fisika adalah fenomena-fenomena yang terjadi di alam baik itu sifat maupun gejalanya. Pembelajaran fisika berkaitan dengan cara mencari tahu alam secara sistematis, sehingga dapat diharapkan dapat menjadi wahana bagi siswa untuk memahami dirinya dan alam sekitarnya serta pengembangannya dapat diterapkan dalam kehidupan sehari-hari (Kawuri et al. 2019). Pemahaman terhadap alam dan lingkungan merupakan salah satu modal dasar untuk menyongsong kehidupan di masa mendatang, yang semuanya bergantung pada temuan-temuan dan terobosan-terobosan dalam bidang sains dan teknologi (Khomaidah \& Harjono, 2019).

Hal ini berarti bahwa, pendidikan sains hendaknya menjadikan siswa tidak sekedar tahu dan hafal tentang konsep-konsep sains, melainkan harus menjadikan siswa untuk mengerti dan memahami konsep-konsep tersebut dan menghubungkan keterkaitan suatu konsep dengan konsep yang lain serta mampu mengaplikasikan konsep tersebut dalam kehidupan sehari-hari (Sukariasih et al.2019; Hunaidah et al. 2019). Namun, dalam kenyataannya pembelajaran sains sulit diwujudkan. Pemahaman konsep fisika kurang mendapat perhatian. Mengapa demikian? Karena untuk materi fisika yang diajarkan lebih banyak menuntut pada kemampuan matematika siswa saja. Ketika siswa ditanya suatu konsep maka yang pertama terpikir oleh siswa adalah persamaannya bukan pengertian atau definisi fisikanya. Sehingga saat materi fisika dijadikan sebagai hapalan atau kurang mengerti tentang konsepnya maka pembelajaran fisika yang diberikan kepada siswa tidak dapat diterapkan secara maksimal dalam kehidupan sehari-hari (Fayanto et al. 2019).

Melihat kenyataan ini maka berbagai upaya telah dilakukan pemerintah untuk menyediakan peluang kepada siswa dalam mencapai pemahaman yang lebih baik. Upayaupaya tersebut antara lain dengan pengembangan metode dan strategi pembelajaran yang lebih sesuai dengan karakteristik dan hakikat sains, melaksanakan MGMP, melaksanakan diklat guru, meningkatkan sarana dan prasarana laboratorium, ataupun melakukan revisi kurikulum secara berkesinambungan. Walaupun upaya-upaya tersebut telah dilaksanakan, tapi kenyataannya tingkat pemahaman siswa terhadap konsep-konsep sains masih tergolong rendah. Hal ini terlihat dari rendahnya hasil belajar siswa dalam aspek kognitif, khususnya siswa Kelas XI-IPA ${ }_{1}$ SMA Negeri 2 Baubau. Rendahnya hasil belajar siswa dalam aspek kognitif tersebut tampak dari analisis hasil ulangan harian mata pelajaran fisika pada materi elastisitas pada semester genap tahun pelajaran 2016/2017 nilai rata-rata ulangan harian hanya mencapai nilai 65 belum memenuhi nilai KKM yang ditetapkan sekolah yaitu 75.

Siswa menganggap Fisika adalah mata pelajaran yang penuh dengan hitungan matematis yang rumit dan susah untuk diingat, dihapal ataupun dipahami bahkan mata pelajaran fisika dijadikan sebagai momok yang menakutkan (Fatmawati et al. 2019; Hunaidah et al. 2018; Fayanto et al. 2019). Untuk mengatasi hal tersebut terjadi, maka pembelajaran yang mungkin antara lain adalah siswa harus melakukan sendiri (praktek) sehingga siswa melihat dan mengalami sendiri fenomena yang terjadi dan dapat dirasakan sendiri, sehingga rasa ingin tahunya dapat terjawab, pengetahuannya bertambah. Melalui praktek siswa dapat meningkatkan keterampilannya dalam mata pelajaran fisika. Untuk menjawab hal ini, perlu adanya model pembelajaran yang sesuai dengan tuntutan kemampuan ketercapaian kompetensi pengetahuan dan keterampilan. Memahami materi dan menerapkan apa yang telah dipelajari merupakan salah satu pencapaian kompetensi.

Melihat hasil belajar dalam aspek kognitif yang dicapai oleh siswa di Kelas XI-IPA ${ }_{1}$ SMA Negeri 2 Baubau masih kurang dan perlu ada upaya peningkatan. Proses pembelajaran fisika selama ini khususnya di Kelas XI-IPA 1 SMA Negeri 2 Baubau kurang mendapatkan respon positif dari siswa dan belum berhasil membantu siswa untuk mencapai pemahaman yang lebih baik terhadap konsep-konsep fisika. Sulitnya pencapaian pemahaman bagi siswa dalam pembelajaran fisika hendaknya menggiring kita untuk berpikir cermat dalam mendisain model pembelajaran. Salah satu caranya adalah merancang pembelajaran fisika berdasarkan pengetahuan awal yang dimiliki siswa. Pembelajaran yang bertujuan untuk 
meningkatkan pemahaman hendaknya memberikan lebih banyak waktu dan kesempatan kepada siswa untuk berinteraksi dengan komponen-komponen dalam proses pembelajaran, dan lebih melatih keterampilan berpikir siswa dalam memecahkan masalah. Rekonstruksi pemahaman umumnya lebih banyak terjadi melalui proses akomodasi daripada proses asimilasi. Oleh sebab itu, belajar untuk pemahaman tidak dapat dilepaskan dari model pembelajaran perubahan konseptual.

Salah satu alternatif model pembelajaran yang dapat diterapkan adalah Model Pembelajaran ICI (Interactive Conceptual Interaction) Berbantuan LKS Berbasis Lingkungan untuk meminimalisir faktor penyebab rendahnya pemahaman dan hasil belajar fisika. Hal ini didasarkan atas premis bahwa pemahaman konsep-konsep fisika memerlukan suatu proses interaktif yang memberi peluang kepada siswa dalam mengembangkan gagasan melalui proses dialog dan berpikir, serta pembentukkan konsepsi ilmiah (Aryani, 2019). Ini terjadi apabila terjadi interaksi yang dapat menimbulkan dialog antara prakonsepsi siswa dengan konsep baru, yang lebih menekankan pada pemberian kesempatan kepada siswa untuk memanfaatkan dan mengembangkan dasar intelektualnya serta memberikan lebih banyak waktu untuk berinteraksi dengan komponen-komponen pembelajaran.

Berdasarkan uraian yang telah dipaparkan, peneliti mencoba mengimplementasikan model Pembelajaran ICI Berbantuan LKS Berbasis Lingkungan dalam pembelajaran fisika di Kelas XI-IPA 1 SMA Negeri 2 Baubau dengan judul penelitian: Upaya Memperbaiki Miskonsepsi dan Meningkatkan Hasil belajar Siswa Kelas Melalui Penerapan Model Pembelajaran ICI. Tujuan dari penelitian ini adalah untuk memperbaiki miskonsepsi dan hasil belajar fisika siswa kelas XI-IPA ${ }_{1}$ melalui penerapan model pembelajaran ICI berbantuan LKS berbasis lingkungan.

\section{Metode}

JenisPenelitian ini adalah classroom action reseach. Subjek penelitian ini adalah siswa Kelas XI-IPA 1 SMA Negeri 2 Baubau semester genap tahun pelajaran 2016/2017 dengan jumlah 35 siswa, siswa laki-laki berjumlah 8 siswa dan siswa perempuan berjumlah 27 siswa. Objek dalam penelitian ini adalah sebagai berikut: (1) Model pembelajaran ICI dengan seting kelas kooperatif, (2) Miskonsepsi siswa, (3) Hasil belajar siswa.Tahapan Penelitian ini dibagi dalam dua siklus dengan masing-masing siklus terdiri dari empat tahapan yaitu: (1) perencanaan, (2) tindakan, (3) observasi/evaluasi, dan (4) refleksi seperti yang disajikanpada Gambar 1.

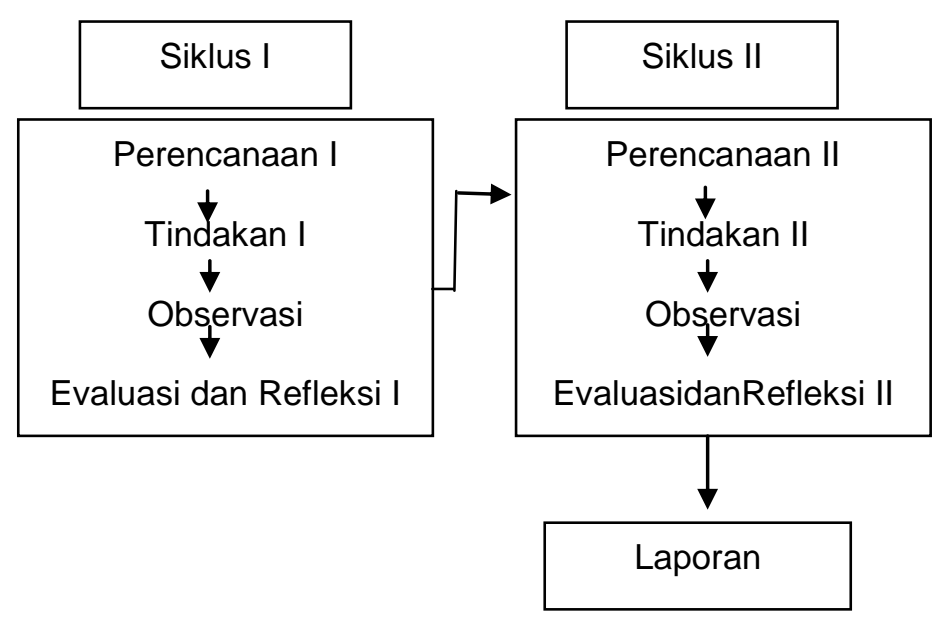

Gambar 1. Desain Pembelajaran PTK dengan model ICI

Dalam melaksanakan pembelajaran dengan menerapkan langkah-langkah pembelajaran model Pembelajaran ICI Berbantuan LKS Berbasis Lingkungan. Dengan langkah- 
langkahnya sebagai berikut:

a. Conceptual Focus

1. Memusatkan perhatian siswa terkait dengan konsep tentang Fluida dan penerapannya dalam kehidupan sehari-hari. Hal ini bertujuan agar siswa fokus terhadap konsep yang akan dibelajarkan, memberikan kesempatan kepada siswa untuk mengembangkan ide-ide baru yang berfokus pada pemahaman konseptual. Ini dilakukan dengan cara melakukan demonstrasi fenomena yang dilakukan di depan kelas dan di halaman sekolah

2. Memberikan pertanyaan-pertanyaan konseptual singkat terkait dengan demonstrasi yang sedang dilaksanakan.

3. Memberikan kesempatan kepada siswa untuk mengemukakan gagasan terkait dengan pertanyaan konseptual yang diajukan peneliti.

4. Menampung semua gagasan siswa tanpa menyalahkan atau membenarkan gagasan mereka.

b. Use Of Teks

1. Memberikan kesempatan kepada siswa mencari, menggali informasi ilmiah tentang konsep Fluida dengan cara membaca literature dan internet.

2. Mengajak siswa melakukan observasi terhadap saluran air yang ada di sekolah terutama yang berkaitan dengan pipa kapiler, kolam sekolah, tower penampungan air, benda-benda disekitar kolam, terkait dengan informasi yang diperoleh dari buku teks dan internet.

c. Research-Based Materials

1. Mengorganisasikan siswa ke dalam kelompok kooperatifnya masing-masing.

2. Membagikan LKS berbasis lingkungan kepada tiap-tiap kelompok.

3. Memberikan kesempatan kepada siswa untuk melakukan percobaan atau penyelidikan, mengetes atau menguji kedalaman konsep yang difasilitasi dengan LKS berbasis lingkungan.

4. Membimbing siswa atau kelompok kooperatif yang mengalami kendala dan mengobservasi aspek psikomotor siswa dalam melakukan praktikum berdasarkan lembar observasi dengan melakukan team teaching bersama guru observer.

d. Classroom Interactions

Pada tahap ini siswa diberikan kesempatan untuk menyampaikan kesimpulan hasil percobaan kepada teman-temannya. Nantinya diharapkan terjadi interaksi antara siswa dengan siswa, siswa dengan peneliti dan observer. Dengan demikian siswa dapat mengetahui apakah konsep yang mereka miliki benar atau salah dan memberikan kesemptan kepada mereka untuk meluruskan konsep mereka yang miskonsepsi.

Intrument penelitian dan teknik pengumpulan data terdiri dari: (1) tes miskonsepsi, (2) tes hasil belajar aspek kognitif, (3) lembar observasi aspek psikomotor dan (4) lembar observasi afektif. Sedangkan teknik analisis data menggunakan analisis kualitatif dan kuantitatif. Analisis miskonsepsi didasarkan pada kriteria keberhasilan tindakan perbaikan miskonsepsi menjadi konsepsi ilmiah minimal 60 \% (Santyasa, 2004). Sedangkan untuk hasil belajar menggunakan ketuntasan secara klasikal.

\section{Hasil dan Pembahasan}

Pelaksanaan tindakan pada siklus pertama dalam proses pembelajarannya sesuai dengan rencana pembelajaran yang dipersiapkan oleh guru. Tahapan-tahapan tindakan pada skenario pembelajaran yang dilaksanakan sesuai tahapan yang dilakulan. Hasil 
penelitian yang diperoleh dari pelaksanaan tindakan pada siklus I meliputi data miskonsepsi siswa dalam memahami konsep dan data hasil belajar. Analisis data miskonsepsi disajikan pada Tabel 1.

Table 1. Data miskonsepsi pada siklus i dan siklus il

\begin{tabular}{lccc}
\hline & Miskonsepsi & Rerata & Persentasi (\%) \\
\hline Siklus 1 & 12,8 & 37,14 \\
Siklus 2 & 7,0 & 20 \\
\hline
\end{tabular}

Dengan mengkonversi jumlah siswa yang mengalami miskonsepsi kedalam persentase dapat diketahui dari 35 orang siswa yang mengikuti proses pembelajaran 12,8 siswa atau 13 siswa siswa masih mengalami miskonsepsi atau sekitar $37,14 \%$ pada siklus 1 (Tabel 1). Sedangkan, pada siklus dua 35 orang siswa yang mengikuti proses pembelajaran, 7 orang siswa masih mengalami miskonsepsi sekitar 20\%. Lebih lanjut, data hasil belajar pada aspek kognitif pada setiap siklus dengan menerapkan model pembelajaran ICI disajikan pada Tabel 2.

Table 2. Data hasil belajar aspek kognitif pada setiap siklus

\begin{tabular}{|c|c|c|c|}
\hline $\begin{array}{l}\text { Data Hasil Belajar Aspek } \\
\text { Kognitif }\end{array}$ & Information & Persentation (\%) & Rerata \\
\hline Siklus 1 & $\begin{array}{l}\text { Tuntas } \\
\text { BelumTuntas }\end{array}$ & $\begin{array}{l}62,86 \\
37,14\end{array}$ & 73,86 \\
\hline Siklus 2 & $\begin{array}{l}\text { Tuntas } \\
\text { BelumTuntas }\end{array}$ & $\begin{array}{l}82,86 \\
17,14\end{array}$ & 84,06 \\
\hline
\end{tabular}

Tabel 2 dapat dijelaskan bahwa rata-rata kelas yang dicapai siswa adalah 73,86 lebih rendah dari nilai rata-rata kkm yang ditetapkan sekolah yaitu 75 (Siklus 1). Dari 35 orang peserta tes hanya 14 orang siswa 37,14\%yang belum tuntas dan 21 orang lagi $(62,86 \%)$ sudah tuntas. Sedangkan pada Siklus 3 rata-rata kelas yang dicapai siswa adalah 84,06 lebih tinggi dari nilai rata-rata kkm yang ditetapkan sekolah yaitu 75 Dari 35 orang peserta tes hanya 6 orang siswa (17,14\%) yang belum tuntas dan 28 orang lagi $(82,86 \%)$ sudah tuntas. Selanjutnya hasil analisis hasil belajar pada aspek psikomotorik disajikan pada Tabel 3.

Table 3. Data hasil belajaraspek psikomotorik pada setiap siklus

\begin{tabular}{lllcc}
\hline & $\begin{array}{c}\text { Data Hasil Belajar } \\
\text { Aspek Kognitif }\end{array}$ & \multicolumn{1}{c}{ Information } & $\begin{array}{c}\text { Jumlah } \\
\text { (Orang) }\end{array}$ & Persentasi (\%) \\
\hline \multirow{2}{*}{ Siklus 1 } & Tuntas & 26 & 74,29 \\
\hline \multirow{2}{*}{ Siklus 2 } & BelumTuntas & 9 & \multirow{2}{*}{24} \\
\hline
\end{tabular}

Berdasarkan analisis ketuntasan belajar (Tabel 3) dengan batas minimal ketuntasan 75, secara klasikal diperoleh 26 siswa termasuk kategori tuntas belajar dari 35 orang siswa yang mengikuti proses pembelajaran. Dengan demikian persentase ketuntasan yang dapat dicapai secara klasikal pada aspek psikomotor adalah 74,29\% (Siklus 1). Sedangkan untuk siklus 2 secara klasikal diperoleh 33 siswa termasuk kategori tuntas belajar dari 35 orang 
siswa yang mengikuti proses pembelajaran. Dengan demikian persentase ketuntasan yang dapat dicapai secara klasikal pada aspek psikomotor adalah 94,29\%. Selanjutnya, Data hasil belajar siswa pada aspek afektif pada setiap siklus disajikan pada Tabel 4.

Table 4. Data HasilBelajarAspekAfektifpadaSetiapSiklus

\begin{tabular}{llcc}
\hline \multicolumn{1}{c}{$\begin{array}{c}\text { Data Hasil Belajar } \\
\text { Aspek Kognitif }\end{array}$} & \multicolumn{1}{c}{ Information } & Jumlah (Orang) & Persentasi (\%) \\
\hline \multirow{2}{*}{ Siklus 1 } & Tuntas & 31 & 88,57 \\
\hline \multirow{2}{*}{ Siklus 2 } & BelumTuntas & 4 & \multirow{2}{*}{94,24} \\
\hline
\end{tabular}

Berdasarkan analisis ketuntasan belajar (Tabel 3) dengan batas minimal ketuntasan B, secara klasikal diperoleh 31 siswa termasuk kategori tuntas belajar dari 35 orang siswa yang mengikuti proses pembelajaran. Sedangkan, pada siklus 2 persentase ketuntasan yang dapat dicapai secara klasikal pada aspek afektif adalah $100 \%$.

Salah satu model pembelajaran inovatif yang memberikan peluang kepada siswa untuk memperbaiki miskonsepsi dan hasil belajar siswa adalah model pembelajaran $\mathrm{ICI}$, yang lebih menekankan pada pemberian kesempatan dan lebih banyak waktu kepada siswa untuk berinteraksi dengan komponen-komponen pembelajaran, baik dengan temannya, guru, dan sumber belajar. Hal ini disebabkan pemahaman konsep-konsep fisika memerlukan suatu proses interaktif yang memberi peluang mengembangkan gagasan melalui proses dialog dan berpikir.

Dalam penerapan model pembelajaran $\mathrm{ICl}$ saat pembelajaran fisika berlangsung. penanaman konsep dalam diri siswa diawali dengan demonstrasi yang bertindak sebagai fokus pengamatan dan diskusi. Melalui demonstrasi diawal pembelajaran, guru sebagai fasilitator dapat menunjukkan fenomena real, memberikan acuan mengenai apa yang akan mereka pelajari, dan mengarahkan siswa memahami fenomena fisis secara lebih nyata dan dapat mempercepat siswa mengkonstruksi pengetahuan barunya secara ilmiah, serta penggunaan Buku teks yang berfungsi sebagai sarana pembelajaran yang menyajikan penjelasan-penjelasan, dan sumber informasi ilmiah. Hal ini dapat membantu siswa memperoleh pengetahuan baru dan upaya pembentukkan pemahaman dalam diri mereka, sebagai hasil interaksi dengan buku teks (Triyaniet al. 2019).

Selain itu pula, dalam pembelajaran siswa lebih banyak diberikan kesempatan untuk berdiskusi dan sharing pendapat baik dengan guru maupun dengan temannya sendiri. Melalui diskusi tentang konsep yang baru saja dipelajari akan membuat mereka tertantang untuk mengerti lebih dalam. Siswa saling mengungkapkan konsep dan gagasan mereka masing-masing, mendengarkan gagasan teman lain, memperdebatkan secara argumentasi dan rasional gagasan mereka yang berbeda. Dari perdebatan itu siswa yang mempunyai gagasan tidak benar, dapat memperbaiki gagasanya dan siswa yang telah memiliki gagasan yang benar lebih yakin akan kebenaran gagasannya yang dibuktikan dengan melakukan demonstrasi dan eksperimen.

Berdasarkan data yang telah disajikan baik dari siklus pertama maupun siklus kedua, diperoleh gambaran bahwa penerapan Model Pembelajaran ICI Berbantuan LKS Berbasis Lingkungan pada Kompetensi 2.2 Menganalisis hukum-hukum yang berhubungan dengan fluida statik dan dinamik serta penerapannya dalam kehidupan sehari-hari dapat mengurangi miskonsepsi dan meningkatkan hasil belajar pada aspek kognitif dan psikomotor. Berikut disajikan pada Gambar 1 grafik yang menggambarkan tingkat miskonsepsi yang dialami 
siswa sebelum diberi tindakan, siklus I dan siklus II.

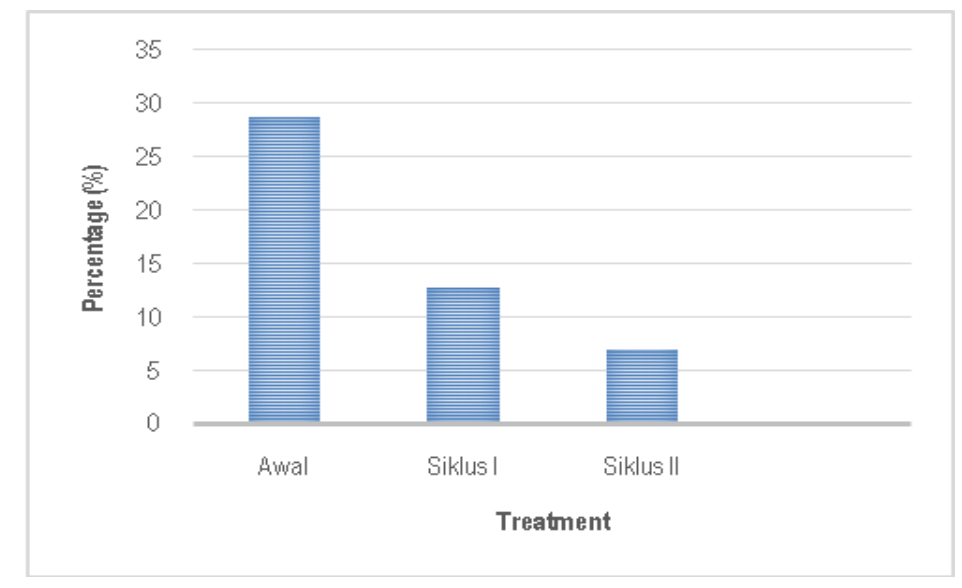

Gambar 2. Data hasil analisis miskonsepsi

Gambar 2 perbandingan jumlah siswa yang mengalami miskonsepsi Sebelum dan sesudah diberikan tindakanatau pada awal pertemuan dari 35 siswa yang mengikuti kegiatan pembelajaran 28,8 siswa atau 29 siswa atau 82,86\% mengalami miskonsepsi. Setelah diberikan tindakan pada siklus I terjadi pengurangan tingkat miskonsepsi, dimana dari 35 siswa yang mengikuti kegiatan pembelajaran 12,8 siswa atau 13 siswa atau sekitar $37,14 \%$ yang masih mengalami miskonsepsi. Sehingga terjadi pengurangan tingkat miskonsepsi sekitar 45,72\%, ini berarti penerapan model pembelajaran ICI berbantuan LKS berbasis lingkungan dapat dikatakan berhasil memperbaiki konsep siswa yang salah menjadi konsep yang ilmiah sesuai kreteria keberhasilan hanya $60 \%$. Pengurangan tingkat miskonsepsi juga teerjadi setelah dilaksanakan kegiatan pembelajaran pada siklus II.

Pada siklus pertama tingkat miskonsepsi siswa lebih tinggi dari siklus kedua hal ini disebabkan oleh beberapa hal diantaranya sperti berikut. 1) Siswa tidak membaca petunjuk yang ada pada LKS sehingga pada saat melaksanakan kegiatan observasi tidak berurutan sesuai dengan konsep yang akan dipelajari, 2) Siswa tidak menuliskan hasil pengamatan secara lengkap, sehingga kesulitan dalam menjelaskan konsep mengapa hal tersebut bisa terjadi, 3) Siswa tidak menganalisa hasil pengamatan dengan konsep-konsep tekanan menurut pendapatnya dan menurut yang ada pada literatur, 4) Siswa tidak mendiskusikan hasil pengamatan dan hasil análisis dengan kelompoknya, 5) Siswa dalam melakukan pengamatan belum maksimum, masih banya ksiswa yang bermain-main saat melakukan pengamatan. Setelah diberikan saran sesuai rekomendasi yang disampaikan sebelum siklus kedua maka terjadi pengurangan tingkat miskonsepsi yang terjadi pada siswa. Jadi secara umum penerapan Model Pembelajaran ICI Berbantuan LKS Berbasis Lingkungan dalam proses pembelajran dapat mengurangi miskonsepsi siswa dalam materi Fluida.

Pengurangan tingkat miskonsepsi yang terjadi pada siswa berimplikasi terhadap peningkatan hasilbelajar yang diperolehsiswa pada masing-masing aspek pada setiap siklusnya. Dari kedua siklus yang dilakukan diperoleh gambaran bahwa pada aspek kognitif terjadi peningkatan hasil belajar dari $62,86 \%$ menjadi $82,86 \%$ atau sebesar $20,00 \%$. Penigkatan hasil belajar ini disebabkan oleh pengurangan tingkat miskonsepsi pada siswa setelah diberikan saran-saran sehingga membawa siswa untuk selalu ingat dengan konsep yang diperbaiki dan konsep baru yang dipelajari. Sehingga dalam menjawab soal siswa tidak kesulitan terlebih lagi soal-soal yang dikerjakan acuannya pada konsep dan berhubungan dengan lingkungan sekitar mereka. 


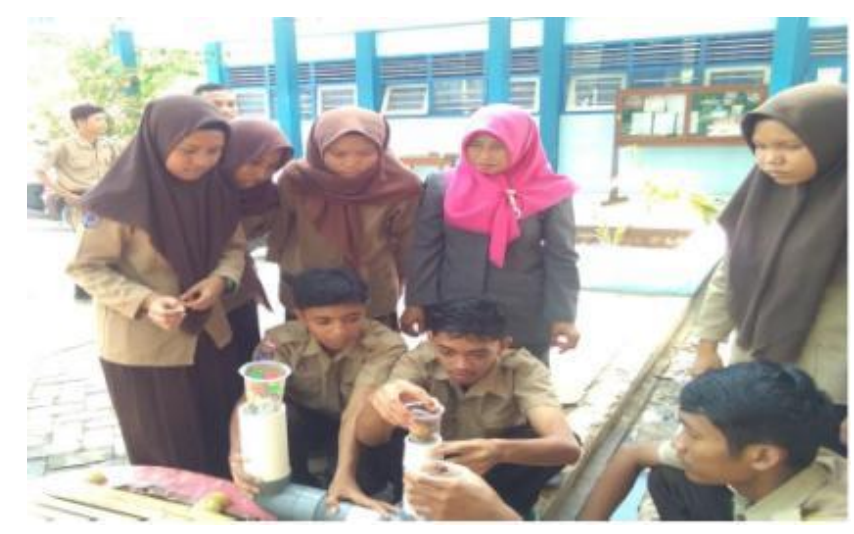

Gambar 3. Aktivitas siswa selama proses pembelajaran fluida

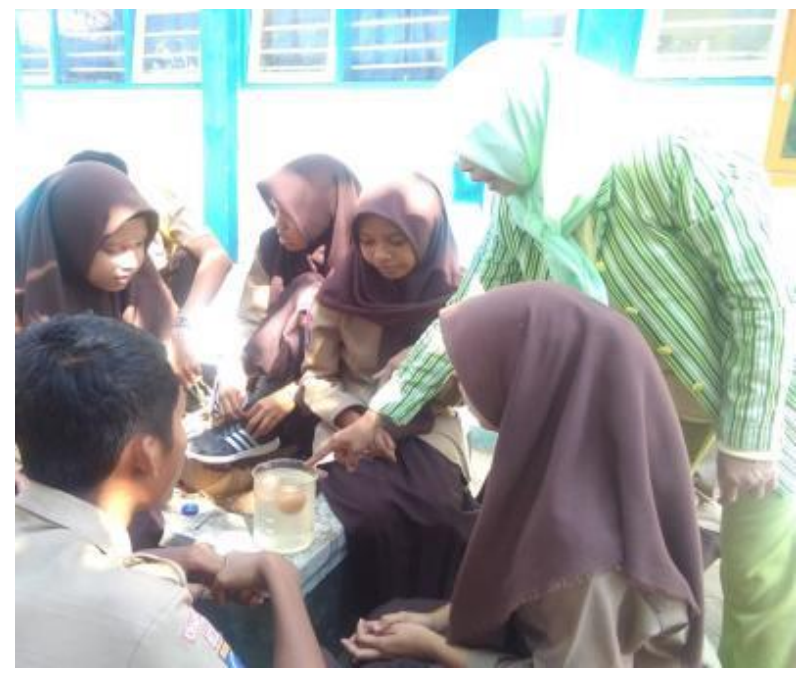

Gambar 4. Aktivitas siswa dan guru selama proses pembelajaran fluida

Peningkatan hasil belajar juga terjadi pada aspek psikomotor, dimana dari persentase ketuntasan yang dicapai pada siklus I yaitu $74,29 \%$ meningkat menjadi $94,29 \%$ atau sekitar $20,00 \%$. Peningkatan hasil belajar pada aspek psikomotor ini terjadi karena kegiatan pembelajaran yang ditekankan pada kegiatan observasi dapat dilakukan oleh siswa dengan baik sesuai dengan petunjuk Iks, terlebih lagi siswa mengikuti saran-saran yang direkomendasikan pada siklus pertama.

Peningkatan hasil belajar juga terjadi pada aspek afektif, dimana dari persentase ketuntasan yang dicapai pada siklus I yaitu $88,57 \%$ meningkat menjadi $100 \%$ atau sekitar $11,43 \%$. Peningkatan hasil belajar pada aspek afektif ini terjadi karena kegiatan pembelajaran sangat menarik karena berhubungan dengan kejadian sehari-hari, serta didukung oleh rasa ingin tahu siswa terhadap masalah-masalah yang dihadapi.

Penerapan Model Pembelajaran ICI Berbantuan LKS Berbasis Lingkungan dalam proses pembelajaran pada kompetensi dasar 2.2 Menganalisis hukum-hukum yang berhubungan dengan fluida statik dan dinamik serta penerapannya dalam kehidupan sehariharisejalan dengan Teori Konstruktivisme. Dimana sertiap siswa aktif secara mental untuk memilih atau mengamati beberapa masukan sensori baru dalam lingkungannya, baik berasal dari pengalaman belajar maupun dari buku-buku teks. Masukan-masukan yang 
diperhatikan dan dipilih siswa kemudian dimaknai dengan menyusun hubungan-hubungan antara masukan sensori baru dengan pengetahuan relevan yang telah dimiliki. Jadi dengan menerapakan Model Pembelajaran ICI Berbantuan LKS Berbasis Lingkungan siswa dapat belajar mandiri, memperbaiki konsep, dan dapat menganalisis kejadian-kejadian alam yang terjadi disekitar lingkungan dengan konsep-konsep yang benar, dan logis serta dapat diterima dengan akal sehat.

\section{Simpulan dan Saran}

Berdasarkan hasil kajian telah diuraikan di atas dapat disimpulkan; (1) Miskonsepsi siswa Kelas XI-IPA 1 SMA Negeri 2 Baubau Tahun Pelajaran 2016/2017 semester genap dapat diperbaiki melalui penerapan Model Pembelajaran ICI Berbantuan LKS Berbasis Lingkungan, (2) Hasil belajar siswa Kelas XI-IPA 1 SMA Negeri 2 Baubau Tahun Pelajaran 2016/2017 semester genap dapat ditingkatkan melalui penerapan Model Pembelajaran ICI Berbantuan LKS Berbasis Lingkungan. Sedangkan saran yang dapat diberikan : (1) Bagi rekan-rekan guru fisika dapat mempertimbangkan penerapan Model Pembelajaran ICI Berbantuan LKS Berbasis Lingkungan dalam proses pembelajaran pada kompetensi dasar 2.2 Menganalisis hukum-hukum yang berhubungan dengan fluida statik dan dinamik serta penerapannya dalam kehidupan sehari-hari di Kelas XI-IPA $A_{1}$, sebagai salah satu alternatif, guna mengurangi miskonsepsi dan meningkatkan hasil belajar siswa. (2) Bagi rekan-rekan guru fisika yang menerapkan Model Pembelajaran ICI Berbantuan LKS Berbasis Lingkungan dalam proses pembelajaran, hendaknya menegaskan tahapan-tahapan urutan kegiatan dan penilaian yang akan dilakukan dalam setiap tahapan, sehingga tujuan dapat tercapai secara efektif dan efisien. (3) Bagi siswa yang sedang mengikuti pembelajaran di kelas XI-IPA khususnya pada materi Fluida, hendaknya menyampaikan konsep yang dimiliki saat mengamati kejadian-kejadian yang ada dilingkungan sekitar, sehingga konsep-konsep yang salah segera dapat diperbaiki.

\section{Daftar Pustaka}

Aryani, W. D., Suhendi, E., Suyana, I., Samsudin, A., \&Kaniawati, I. (2019, November). Effectiveness of implementation interactive conceptual instruction (ICI) with computer simulation to overcome students' misconceptions about newton's law of gravitation. In Journal of Physics: Conference Series (Vol. 1280, No. 5, p. 052011). IOP Publishing.

Hunaidah, M., Armin, A., \&Fayanto, S. (2018, May). Penerapan model pembelajaran PredictObserve-Explain (POE) dengan metode demonstrasi untuk meningkatkan aktivitas dan hasil belajar IPA Fisika materi pokok kalor Kelas VII2 SMP Negeri 15 Kendari. In Quantum: Seminar Nasional Fisika, danPendidikanFisika (pp. 293-298).

Hunaidah, M., Sukariasih, L., \&Saputra, I. G. P. E. (2019). Penerapan model pembelajaran discovery untuk meningkatkan keterampilan proses sains dan penguasaan konsep IPA peserta didik kelas VIIID SMP Kartika XX-6 Kendari. JPFT (Jurnal Pendidikan Fisika Tadulako Online), 7(3).

Fatmawati, F., Sukariasih, L., Fayanto, S., \&Retnawati, H. (2019, May). investigating the effectiveness of inquiry learning and direct learning models toward physics learning. In First International Conference on Progressive Civil Society (ICONPROCS 2019). Atlantis Press.

Fayanto, S., Misrawati, M., Sulisworo, D., Istiqomah, H. F. N., \&Sukariasih, L. (2019). The implementation of multimedia on physics learning based on direct instruction model in the topic of light. Indonesian Journal of Learning Education and Counseling, 1(2), 124132. 
Fayanto, S., Musria, M., Erniwati, E., Sukariasih, L., \&Hunaidah, H. (2019). Implementation of quantum teaching model on improving physics learning outcomes in the cognitive domain at junior high school. IJIS Edu: Indonesian Journal of Integrated Science Education, 1(2), 131-138.

Kawuri, M. Y. R. T., Ishafit, I., \&Fayanto, S. (2019). Efforts to improve the learning activity and learning outcomes of physics students with using a problem-based learning model. IJIS Edu: Indonesian Journal of Integrated Science Education, 1(2), 105-114.

Khomaidah, S., \& Harjono, N. (2019). Meta-analisis efektivitas penggunaan media animasi dalam meningkatkan hasil belajar IPA. Indonesian Journal of Educational Research and Review, 2(2), 143-148.

Santyasa, I. W. (2004). Penerapan model ICI dalam pembelajaran fisika sebagai upaya perbaikan miskonsepsi, pemahaman konsep, dan hasil belajar siswa kelas I SMU Negeri 1 Singaraja pada Semester I. Laporan penelitian.

Sukariasih, L., Ato, A. S., Fayanto, S., Nursalam, L. O., \& Sahara, L. (2019, October). Application of SSCS model (Search, Solve, Create and Share) for improving learning outcomes: the subject of optic geometric. In Journal of Physics: Conference Series (Vol. 1321, No. 3, p. 032075). IOP Publishing.

Triyani, G., Danawan, A., Suyana, I., \&Kaniawati, I. (2019, November). An investigation of students' misconceptions about momentum and impulse through interactive conceptual Instruction (ICl) with computer simulation. In Journal of Physics: Conference Series (Vol. 1280, No. 5, p. 052008). IOP Publishing 